\title{
Effect of copaiba oil on correction of abdominal wall defect treated with the use of polypropylene/polyglecaprone mesh $^{1}$
}

\author{
Edson Yuzur Yasojima', Renan Kleber Costa Teixeira" ${ }^{\mathrm{II}}$, Abdallah de Paula Houat ${ }^{\mathrm{III}}$, Felipe Lobato da Silva Costa ${ }^{\mathrm{III}}$, Edvaldo \\ Lima Silveira $^{\text {Iv }}$, Marcus Vinicius Henriques Britov, Gaspar de Jesus Lopes Filhovi \\ ${ }^{I}$ Fellow PhD degree, Postgraduate Program in Surgical Gastroenterology, UNIFESP, Sao Paulo-SP, Brazil. Conception and design of the study, surgical \\ procedures, interpretation of data, manuscript writing, critical revision.

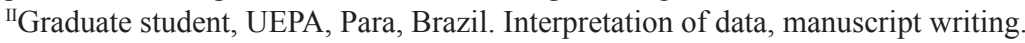

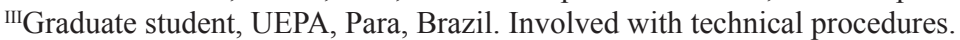

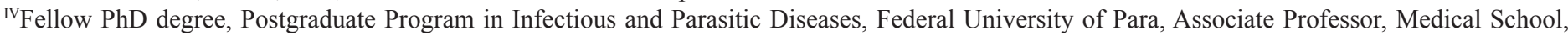 \\ UEPA, Para, Brazil. Histological examinations, critical revision. \\ ${ }^{\mathrm{V}} \mathrm{PhD}$, Associate Professor, Medical School, UEPA, Para, Brazil. Conception and design of the study, interpretation of data, critical revision. \\ ${ }^{\mathrm{v}} \mathrm{PhD}$, Associate Professor, Division of Surgical Gastroenterology, Department of Surgery, UNIFESP, Sao Paulo-SP, Brazil. Interpretation of data, \\ critical revision.
}

\begin{abstract}
PURPOSE: To evaluate the effects of copaiba oil on the correction of abdominal defect treated with the use of polypropylene/ polyglecaprone mesh in rats.

METHODS: A defect in the abdominal wall was created and corrected with polypropylene/polyglecaprone mesh in 36 rats. They were randomly distributed into three groups: control, copaiba by oral administration (gavage) and copaiba oil dip in the mesh. Euthanasia was performed after seven, 14 and 21 post-operative days. The healing process was analyzed regarding the meshes and macroscopic and microscopic aspects.

RESULTS: All animals had abdominal adhesions, which were smaller in the copaiba (gavage) group ( $<<0.05$ ). In microscopy, all animals had an acute inflammation stage and the inflammatory response was best characterized by foreign body-type granulomas around the mesh fragments, which was not found in the mesh fragments within the copaiba dip group. There was a greater area of necrosis and fibrosis in the copaiba dip group compared to the control group $(\mathrm{p}<0.05)$. The copaiba (gavage) group had a greater quantity of collagen fibers compared to the control group.

CONCLUSION: Copaiba oil administered by gavage decreased the amount of abdominal adhesions, besides accelerating the process of collagen fibers formation, without damages within the early stages of healing. However, when used by dip directly on the mesh, it had corrosive effects compromising the healing process of the abdominal wall.
\end{abstract}

Key words: Surgical Mesh. Collagen. Wound Healing. Rats. 


\section{Introduction}

The closure of the abdominal wall is an odd surgery stage, since performing a proper closure of the abdominal cavity can prevent or mitigate some of the potential complications arising from surgeries. Because of this, there are a variety of techniques and materials that can be used in the procedure, demonstrating surgeons' concern with regards to these complications ${ }^{1,2}$.

Incisional hernia is one of the most frequent complications of abdominal surgeries, regarded as a protrusion of abdominal contents through a weak point in the wall, constituted by the scar of a previous surgery ${ }^{3}$. Its incidence varies between 5 to $10 \%$ after laparotomy and its recurrence may be up to $46 \%{ }^{4}$.

The treatment of incisional hernias is essentially surgical. There are several techniques for their correction, as for example primary suture of the wall ${ }^{5}$; however the best results for this pathology are obtained by using prostheses reinforcement, with which the chances of relapse vary between 3 to $17 \%$.

Currently, polypropylene meshes are the most used prosthesis for the correction of hernias ${ }^{7}$; however, because they made of unabsorbed threads, these meshes cause a great immune response, which leads to the formation of large areas of fibrosis and decreased mobility of the abdominal wall ${ }^{8}$. Nevertheless, the use of meshes only made of absorbable threads did not show to be more efficient than meshes made of unabsorbed threads, since the first do not diminish the chances of relapses as the later 9 .

With the knowledge of this, prostheses with unabsorbed and absorbable threads were made in order to minimize the negative effects and maximize the advantages of each type of mesh $^{10}$. Polypropylene/polyglecaprone prosthesis are currently excelling in this area, as can be seen in a recent clinical study, which showed a lower rate of post-operative pain in patients treated with polypropylene/polyglecaprone meshes compared to patients who received polypropylene meshes ${ }^{11}$.

The postoperative pain control is of great importance for hernia surgery, since the use of anti-inflammatory drugs may reduce healing responses ${ }^{12,13}$. Copaiba oil - a medicinal plant of the Amazon region, Brazil-stands today at the level of the public policies of the World Health Organization to encourage the use of medicinal plants; since copaiba oil has proven to have antiinflammatory and healing effects ${ }^{15,16}$.

Thus, the aim of this study was to evaluate the effects of copaiba oil on the correction of abdominal defects treated with the use of polypropylene/polyglecaprone meshes in rats.

\section{Methods}

Before the start of the project, it was approved by the Ethics Committee in the Use of Animals of the State University of Para (UEPA) (Protocol 10/11). 36 Wistar rats (Rattus norvegicus) were used, aged about 120 days and weight ranging from 260 to $300 \mathrm{~g}$, from the Animal Colony of the Experimental Surgery Laboratory of UEPA. The animals were randomly distributed into three groups, each with 12 animals, namely:

- Control group (CG), only treated with meshes.

- Copaiba gavage group (CGG), treated with meshes and $0.63 \mathrm{ml} / \mathrm{Kg}$ copaiba oil, by gavage, seven days prior to the deployment of the meshes.

- Copaiba dip group (CDG), treated with meshes dipped in copaiba oil for 15 minutes.

These groups were subdivided into three subgroups of four animals each to assess the time of action of copaiba oil-seven, fourteen and twenty-one postoperative days- when euthanasia of animals of each subgroup was performed.

The animals were anesthetized with ketamine hydrochloride $(70 \mathrm{mg} / \mathrm{Kg})$ and xylazine hydrochloride $(10 \mathrm{mg} /$ $\mathrm{Kg}$ ), administered intraperitoneally. Once animals' anesthesia was confirmed, was performed the epilation of the abdominal region, followed by antisepsis of the skin. Subsequently, was performed a median four centimeters incision on both sides and the exposure of the aponeurotic muscle layer.

Was followed with the excision of the ventral part of the abdomen, involving the aponeurotic muscle layer and the peritoneum with two centimeters longitudinal axis and two centimeters transversal axis, in order to create a defect in the aponeurotic muscle.

This defect was corrected in all groups with the placement of polypropylene/polyglecaprone meshes with three centimeters longitudinal axis and three centimeters transversal axis, attached at the edges with eight stitches (6-0 nylon thread) separated, equidistant, needled and atraumatic, with five semi-knots in each stitch, leaving the prosthesis margins over the anterior aponeurotic plane.

Seven days before the creation of the defect, the animals of group CGG received $0.63 \mathrm{ml} / \mathrm{Kg}$ copaiba oil, by gavage. For the $\mathrm{CDG}$, the meshes were dipped in copaiba oil for 15 minutes before attaching them to the animals.

After animals' euthanasia, according to the scheduled date for each subgroup, was removed a fragment from the abdominal wall containing the entire mesh, before it was realized 
the macrospic analyzed, studying the presence of incision hernias, infections, dehiscences or fistulas, and the number of adhesions. This fragment was stored in 10\% buffered formaldehyde and used for histopathological analysis by means of hematoxylin, eosin and Masson's trichrome coloration.

Inflammatory response parameters were analyzed (necrosis, type of granuloma, fibrosis, and collagen fibers intensity). These parameters were classified as 0: absence; 1: mild; 2: moderate; and 3: intense. The results were analyzed by KruskalWallis test adopting 5\% significance level.

\section{Results}

Through macroscopic analysis, it was observed that not all animals studied had incision hernias, infections, dehiscences or fistulas. However, all animals studied had formation of adhesions between the meshes and the abdominal organs, showing statistically significant difference between the groups in the three periods studied (Table 1).

TABLE 1 - Average number of adhesions between the mesh and the abdominal organs in accordance with the group and the time of animals' euthanasia.

\begin{tabular}{cccc}
\hline Group & \multicolumn{3}{c}{ Time } \\
& 7 days & 14 days & 21 days \\
\hline CG & 2.75 & 3 & 3.75 \\
CGG & 1.75 & 1 & 1.75 \\
CDG & 3 & 2.5 & 3.5 \\
\hline
\end{tabular}

$\mathrm{p}<0.05$ (Kruskal-Wallis CGG x CG and CGG x CDG in the three periods studied)

All animals studied showed acute inflammatory response, which was characterized by the presence of oedema, vascular congestion and infiltrated with predominance of neutrophils. Regarding the quantity of other immune system components, there was a smaller amount of macrophages in CGG in relation to CDG $(\mathrm{p}=0.008)$ in the three periods studied. There was no difference between the groups regarding giant cells. The amount of lymphocytes was smaller in the CGG compared to the CG (p $=0.0168)$ and the CDG $(p=0.0168)$ in the three periods studied. There was no statistical difference between the periods studied and the inflammatory response in each group (Figures 1 to 3 ).
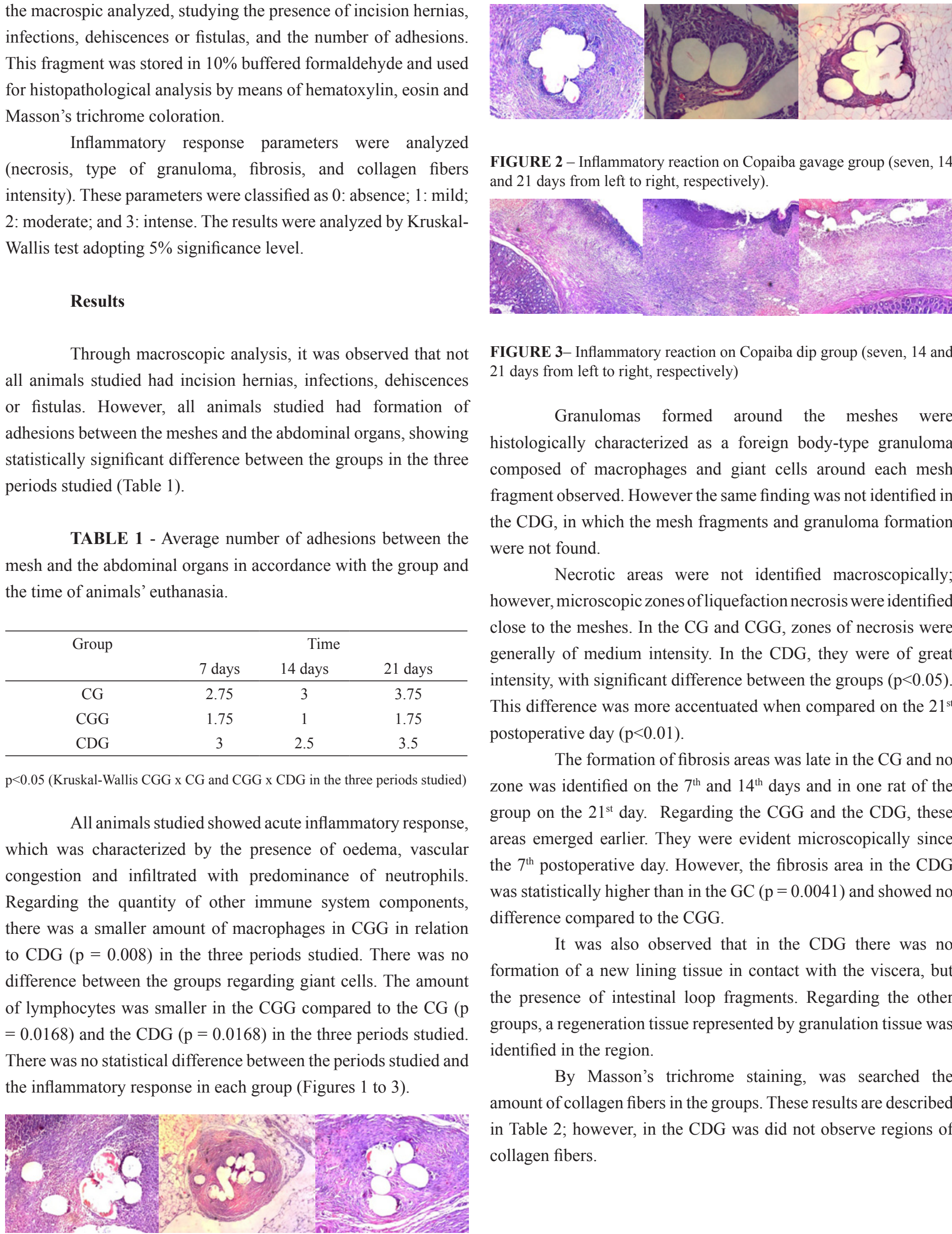

FIGURE 2 - Inflammatory reaction on Copaiba gavage group (seven, 14 and 21 days from left to right, respectively).

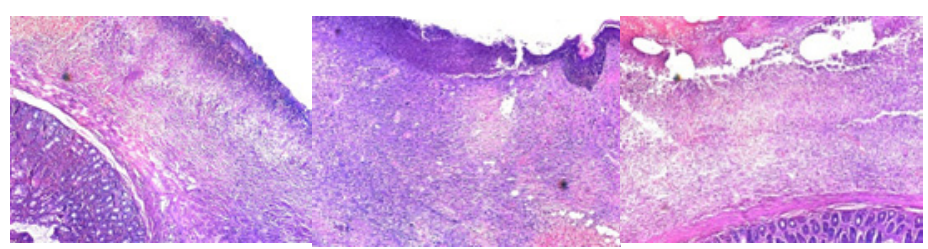

FIGURE 3- Inflammatory reaction on Copaiba dip group (seven, 14 and 21 days from left to right, respectively)

Granulomas formed around the meshes were histologically characterized as a foreign body-type granuloma composed of macrophages and giant cells around each mesh fragment observed. However the same finding was not identified in the $\mathrm{CDG}$, in which the mesh fragments and granuloma formation were not found.

Necrotic areas were not identified macroscopically; however, microscopic zones of liquefaction necrosis were identified close to the meshes. In the CG and CGG, zones of necrosis were generally of medium intensity. In the CDG, they were of great intensity, with significant difference between the groups $(p<0.05)$. This difference was more accentuated when compared on the $21^{\text {st }}$ postoperative day $(\mathrm{p}<0.01)$.

The formation of fibrosis areas was late in the CG and no zone was identified on the $7^{\text {th }}$ and $14^{\text {th }}$ days and in one rat of the group on the $21^{\text {st }}$ day. Regarding the CGG and the CDG, these areas emerged earlier. They were evident microscopically since the $7^{\text {th }}$ postoperative day. However, the fibrosis area in the CDG was statistically higher than in the GC $(p=0.0041)$ and showed no difference compared to the CGG.

It was also observed that in the CDG there was no formation of a new lining tissue in contact with the viscera, but the presence of intestinal loop fragments. Regarding the other groups, a regeneration tissue represented by granulation tissue was identified in the region.

By Masson's trichrome staining, was searched the amount of collagen fibers in the groups. These results are described in Table 2; however, in the CDG was did not observe regions of collagen fibers.

FIGURE 1 - Inflammatory reaction on control group (seven, 14 and 21 days from left to right, respectively). 
TABLE 2 - Average intensity of collagen fibers according to the group and the time of animals' euthanasia.

\begin{tabular}{cccc}
\hline Group & \multicolumn{3}{c}{ Time } \\
& 7 days & 14 days & 21 days \\
\hline CG & 0.5 & 1.5 & 2.25 \\
CGG & 1 & 2.25 & 2.75 \\
CDG & 0 & 0 & 0 \\
\hline
\end{tabular}

p $<0.05$ (Kruskal-Wallis CG7 x CG21 and CGG7 x CGG21 and CG x CGG)

\section{Discussion}

The process of wound healing involves a series of microscopic morphological events that encompass multiple overlapping events after the injury, including coagulation, leukocytes recruitment, deposition of cellular matrix, reepithelialization, and resolution of the inflammation process, resulting in a remodeling of the initial wound forming a mature $\operatorname{scar}^{17}$.

The use of non-hormonal anti-inflammatory drugs during postoperative days has the capacity to decrease pain and modulate inflammation; however, their use should be cautious, because they can slow down the healing process and increase the chances of complications ${ }^{18}$. Some anti-inflammatory drugs have already been tested in the healing of rats' abdominal walls, and the results remain controversial, depending on the drug group studied ${ }^{12,13,18}$.

Copaiba oil is derived from the trunk of trees from the genus Copaifera. Various effects have been attributed to it; some of which have been proven scientifically, especially regarding healing and anti-inflammatory effects ${ }^{15,16}$. This study aimed to analyze an alternative to conventional treatment with antiinflammatory drugs, using this medicinal plant.

The absence of dehiscence, fistulas or infections in all animals studied demonstrates that copaiba oil did not interfere in the process of healing of abdominal wall with enough intensity to cause early clinical changes as occurred in studies using tenoxicam $^{13}$ and meloxican ${ }^{18}$. Macroscopic results were similar to those found by Pundek et al. ${ }^{19}$ studying polypropylene/ polyglecaprone meshes.

Adhesions result of fibrin ooze and they take place after any type of trauma. These exudates entail temporary adhesions and can delay the healing process. Almost all meshes may produce adhesions when they are in contact with the intestinal surface and this process is determined by the size of the pores and by the structure of the surface area of the mesh ${ }^{20}$.

In the analysis of the amount of adhesions, the CGG showed a smaller amount compared to the other groups. This probably occurred due to the fact that copaiba oil, administered by gavage, modulated the inflammatory response by reducing aggression between the parietal and visceral serosa, thereby reducing the formation of adhesions ${ }^{21}$. Regarding the $\mathrm{CDG}$, it was expected that this group could have a greater amount of adhesions, since a study by Souza Junior et al. ${ }^{22}$ demonstrated that when they applied copaiba oil to the peritoneal cavity of rats, all of them showed the formation of adhesions, because they did not absorb it completely.

The inflammatory response did not show great difference between the groups, the most striking being the absence of granuloma in the CDG. This fact should have occurred due to the disappearance of mesh fragments (not identified in microscopic analysis - Figure 3), possibly resulting from the corrosive effect of copaiba oil on the meshes, destroying them and not producing a foreign body-type response.

Such a corrosive effect of the oil studied was identified in a study by Botelho et al..$^{23}$ in which after the administration of high oral doses of copaiba oil, it was possible to identify gastric and cecum ulcers; places where food stays longer. This fact demonstrated the deleterious effect of copaiba oil. This way, soaking the meshes with copaiba oil dip allows understanding that the meshes are initially degraded and that, after their deployment in the abdominal wall, they are rapidly degraded by oil, as well as by the body's inflammatory response.

This corrosive effect should also have been responsible for the largest area of necrosis observed in the CDG. This effect should not only impair the healing of the abdominal wall by the increase in inflammatory response, but possibly damage next organs; which did not occur in this experiment.

The more exacerbated fibrotic process in the CDG compared to that in the CG must have occurred not only because of the corrosive power of copaiba oil -that should have damaged several areas around the mesh- but also, due to the fact of not being totally absorbed into the abdominal cavity. This would create a chemical irritation of the peritoneum, leading to fibrin deposits and formation of abdominal adhesions, which were identified in this study; although the differences were not significant regarding the CG.

The collagen fibers studied in the groups were not identified in the CDG; probably because this group did not show an exuberant acute inflammatory response represented by liquefaction necrosis; since the healing process will only start after the end of this initial inflammatory response. However, the CGG showed a greater amount of collagen fibers compared to the 
CG, demonstrating that the copaiba oil improved healing of the animals' abdominal walls.

This study found that copaiba oil administered by gavage had effect on the body's immune response; however, the accurate determination of the mechanisms through which it operated was not possible. For these reason, it is necessary to carry out new studies in order to identify such mechanisms.

\section{Conclusion}

Copaiba oil administered by gavage decreased the quantity of abdominal adhesions and accelerated the process of collagen fibers formation, without damaging the early stages of healing. However, when used by direct dip on the mesh, it showed corrosive effect damaging the healing process of the abdominal wall.

\section{References}

1. Lenharo S, Mantovani M. Estudo comparativo do fechamento da incisão mediana abdominal por planos e com uso de pontos subtotais e tela de poliglactina 910, em raros. Acta Cir Bras. 1998;13(2):1005 .

2. Tera H, Aberg C. Tissue strength of structures involved in musculoaponeurotic layer sutures in laparotomy incisions. Acta Chir Scand. 1976;142:349-55.

3. Mardegam MJ, Bandeira COP, Novo NF, Juliano Y, Amado CAB, Fagundes DJ. Modelo experimental de hérnia ventral em ratos. Acta Scientiarum. 2001;23(3):683-9.

4. Butler CE, Prieto VG. Reduction of adhesions with composite AlloDerm / polypropylene mesh implants for abdominal wall reconstuction. Plast Reconstr Surg. 2004;114(2):464-73.

5. Baroncello JB, Czeczko NG, Malafaia O, Ribas-Filho JM, Nassif PAN, Dietz AU. O uso de telas Parietex ${ }^{\circledR}$ e Surgisis $^{\circledR}$ na correção de defeitos produzidos na parede abdominal de coelhos. Arq Gastroenterol. 2008;45(4): 323-9.

6. Gianlupi A, Trindade MRM. Comparação entre o uso de fio inabsorvível (polipropileno) e fio absorvível (poliglactina 910) na fixação de prótese de polipropileno em correção de defeitos músculo-aponeurótico da parede abdominal. Estudo experimental em ratos. Acta Cir Bras. 2004;19(2): 94-102.

7. Gonzalez R, Rodeheaver GT, Moody DL, Foresman PA, Ramshaw BJ. Resistance to adhesion formation: A comparative study of treated and untreated mesh products placed in the abdominal cavity. Hernia. 2004;8:213-9.

8. D'Acampora JA, Kestering DM, Soldi MS, Rossi LF. Experimental study comparing the tensile strength of different surgical meshes following aponeurotic-muscle deformity synthesis on Wistar rats. Acta Cir Bras. 2007;22(1):22-9.

9. Lamb JP, Vitale T, Kaminski DL. Comparative evaluation of synthetic meshes used for abdominal wall replacement. Surgery. 1983;176:271-6.

10. Araújo URMF, Czeczko NG, Deallarmi A, Hemoviski FE, Araújo HVCP. Escolha do material da tela para disposição intra-peritoneal na correção cirúrgica de defeitos herniários da parede abdominal. Arq Bras Cir Dig. 2010;23(2):118-21.

11. Smiettanski M. Randomized clinical trial comparing a polypropylene with a poliglecaprone and polypropylene composite mesh for inguinal hernioplasty. Br J Surg. 2008;95:1462-8.

12. Tognini JRF, Goldenberg S, Simões MJ, Sauer L, Melo RL, Ortiz PLA. Efeito do diclofenaco de sódio na cicatrização da parede abdominal de ratos. Acta Cir Bras. 1998;13(3):167-71.

13. Watanabe ALC, Watanabe LM. Efeitos do tenoxican sobre a cicatrização da parede abdominal: estudo experimental em ratos. Acta Cir Bras. 2005;20(2):140-3.

14-. Akerele O. Summary of WHO guidelines for assessment of herbal medicines. HerbalGram. 1993;28:13-9.

15. Brito NMB, Simoes MJ, Pessoa AF, Melo MCF. Efeitos do óleo de copaiba na cicatrização de feridas cultaneas abertas em ratos. Rev Para Med. 1998;12(1):28-32.

16. Veiga Junior VF, Rosas EC, Carvalho MV, Henriques MG, Pinto AC. Chemical composition and anti-inflammatory activity of copaiba oils from copaifera cearensis Huber ex Ducke, Copaifera reticulata and Copaifera multijuga Hayne: a comparative study. J Ethnopharmacol. 2007;112(2):248-54.

17. Ashcroft GS, Jeong MJ, Ashworth JJ, Hardman M, Jin W, Moutsopoulos N, Wild T, McCartney-Francis N, Sim D, McGrady G, Song XY, Wahl SM. Tumor necrosis factor-alpha (TNF-a) is a therapeutic target for impaired cutaneous wound healing. Wound Repair Regen. 2012;20(1): 38-49.

18. Tognini JRF, Fagundes DJ, Novo NF, Juliano Y. Estudo biomecânico e morfológico da cicatrização da parede abdominal sob ação de meloxicam. Acta Cir Bras. 2000;15(3):10-5.

19. Pundek MRZ, Czeczko NG, Yamamoto CT, Pizzatto RF, Czeczko LEA, Dietz UA, Malafaia O. Estudo das telas cirúrgicas de polipropileno/poliglecaprone e de polipropileno/polidioxanona/ celulose oxidada regenerada na cicatrização de defeito produzido na parede abdominal de ratos. Arq Bras Cir Dig. 2010;23(2):94-9.

20. Naufel AM, Czeczko NG, Mafafaia O, Ribas-Filho JM, NaufelJunior CR, Dietz UA, Marinho-Júnior CH, Sucharski EE. Comparative study between meshes of polyester with collagen and polytetrafluoroethylene in the repair of defects produced in abdominal wall of rats. Acta Cir Bras. 2012;27(7):454-9.

21. Simões JC, Battaglin FS, Outi DNE. Aplicação tópica de glicocorticoides e avaliação de aderências intraperitoneais em ratos. Rev Med Res. 2010;12(4):118-23.

22. Souza Júnior OG, Guimarães Neto HP, Pinto NT, Santos MT, Carvalho RA. Achados macroscópicos na cavidade peritoneal de ratos, após aplicação do óleo de copaíba. Rev Para Med. 2002;16(1):14-8.

23. Botelho NM, Carvalho RKV, Matos LTMB, Lobato RC, Corrêa SC. Efeito subagudo de altas doses do óleo de Copaíba nos níveis séricos de enzimas hepáticas em soro de ratos. Rev Para Med. 2010;24(3):51-6

\section{Correspondence:}

Edson Yuzur Yasojima

Travessa Perubebui, 2326 66050-420 Belém - PA Brasil

Tel.: (55 91)9991-8882

yasojima@globo.com

Received: September 17, 2012

Review: November 18, 2012

Accepted: December 19, 2012

Conflict of interest: none Financial source: none

${ }^{1}$ Research performed at Experimental Surgery Laboratory, School of Medicine, State University of Para (UEPA), Belem-PA, Brazil. Part of PhD Thesis degree, Postgraduate Program in Surgical Gastroenterology, Federal University of Sao Paulo (UNIFESP). Tutor: Gaspar de Jesus Lopes Filho. 